\title{
THE EFFECTS OF EXTENSIVE GRAZING ON THE VEGETATION OF A LANDSCAPE-SCALE RESTORATION SITE
}

\author{
Peter A. Stroh ${ }^{1, *}$, John BragG ${ }^{2}$, Peter Carey $^{3,4}$, Carol Laidlaw $^{2}$, Martin Lester $^{2}$, \\ J. Owen Mountford ${ }^{5}$, Geoff Smith ${ }^{6}$, Tim H. Sparks ${ }^{7,8}$, Stuart Warrington ${ }^{2}$ \\ and Francine M. R. Hughes ${ }^{9}$ \\ ${ }^{1}$ Botanical Society of Britain and Ireland (BSBI), Cambridge University Botanic Garden, 1 Brookside, \\ Cambridge CB2 1JE, United Kingdom \\ ${ }^{2}$ National Trust, Wicken Fen, Wicken, Cambridgeshire, CB7 5XP, United Kingdom \\ ${ }^{3}$ Bodsey Ecology Ltd. Ramsey, Cambridgeshire, UK PE262XH, United Kingdom \\ ${ }^{4}$ Department of Plant Sciences, University of Cambridge, Cambridge, CB2 3EA, United Kingdom \\ ${ }^{5}$ Centre for Ecology and Hydrology, Wallingford, OX10 8BB, United Kingdom \\ ${ }^{6}$ Specto-Natura Ltd. Impington, Cambridgeshire, CB24 9PL, United Kingdom \\ ${ }^{7}$ Department of Zoology, Poznań University of Life Sciences, Wojska Polskiego 71c, 60-625 Poznań, Poland \\ ${ }^{8}$ Museum of Zoology, University of Cambridge, Downing Street, Cambridge CB2 3EJ, UK \\ ${ }^{9}$ Global Sustainability Institute, Anglia Ruskin University, Cambridge CB1 1PT, UK \\ *Corresponding author: Pete Stroh peter.stroh@bsbi.org
}

Abstract.

The Wicken Fen Vision (Cambridgeshire, UK) is a landscape-scale habitat restoration project that uses process-driven, open-ended approaches to develop habitats on highly degraded and drained peat soils of former intensive arable land. The project land is extensively grazed with herds of free-roaming, minimally managed herds of Highland cattle and Konik horses. In one 119 ha area, seven $25 \mathrm{~m} \times 25 \mathrm{~m}$ grazing exclosures were erected and vascular plant species were recorded from 2007 to 2017. Plant species data were analysed to (1) compare changes in plant species composition and diversity in grazed and ungrazed areas; (2) use plant species traits and plant-environment associations to explore the nature of changes in plant composition; (3) use remote sensing to explore changes in vegetation structure; (4) examine the influence of land use histories on grazing outcomes in different parts of the site.

There was a clear divergence through time between grazed and ungrazed areas, attributed to significantly greater canopy height, Ellenberg L (Light) and Ellenberg $N$ (fertility) values within the exclosures. Species richness was significantly higher in grazed compared with ungrazed areas and species assemblages separated through the study period. After ten years, extensive free-roaming grazing has had significant impacts on vegetation structure and species richness but effects varied across the study site because of differing historical land use.

Key words: Exclosures, grazing impacts, landscape-scale, low-intensity grazing, open-ended restoration, species richness, species traits

\section{INTRODUCTION}

Managed conservation grazing within nature reserves in the temperate grasslands of northern Europe has been shown to have a positive effect on species diversity (e.g. Dormaar \& Willms, 1998; Stroh et al., 2019). However, this is a complicated relationship which is dependent upon the size and species of livestock, stocking density, the timing of grazing, and the grazing environment (Smith \& Ruston, 1994; Bakker et al., 2003; Pakeman, 2004; Pavlů et al., 2006). Grazing management may also produce different effects at different spatial scales (Chaneton \& Facelli, 1991; Olff \& Ritchie, 1998).

In some countries of Europe abandonment of agricultural land has led to the possibility of larger ar- eas being set aside for nature conservation (Ustaoglu $\&$ Collier, 2018), whilst in other countries opportunities for large scale habitat creation have been guided by policy. In the UK there has been a recognition of the need to increase the overall area devoted to nature conservation, especially in lowland England (Colston, 2003) and at the same time to reduce habitat fragmentation and increase habitat connectivity (Lawton, 2010). Since the 1990s several UK landscape-scale nature conservation projects have been initiated on ex-agricultural areas, with new approaches to habitat creation involving more emphasis on natural processes such as flooding and naturalistic grazing, to deliver the developing habitats.

This new frame of reference is a response to an 
increasing interest in allowing ecosystem processes to manage land and to the practicalities and costs of managing larger areas. However, the soils and hydrology of ex-arable land are usually highly modified due to historic land use practices (Stroh et al., 2013), with subsequent change in function. Such areas provide novel starting points for habitat creation with consequent unknown outcomes (Hughes et al., 2005).

Many landscape-scale restoration initiatives, e.g. the Knepp Wildland Project (UK), have introduced systems of low density, extensive grazing that attempt as much as possible to create a free-roaming grazing and browsing model which may contribute towards a dynamic habitat mosaic (Tree, 2018). Extensive grazing has been defined as the point at which production is higher than utilisation of the forage by grazing animals (Bakker, 1998). The current popularity of such systems is in part based on a somewhat contested understanding of what pre-agricultural landscapes might have looked like during the Holocene with regard to the influence that wild grazers had on the balance of woodland and open land (e.g. Birks, 2005; Vera et al., 2006; Kirby \& Baker, 2013). In the new low-intensity grazing systems, human intervention is reduced as much as possible while complying with national animal welfare regulations, though some projects market meat. Typically, grazing is over large areas by herds that are mixed in species, age and sex. The location of each project along a grazing spectrum that stretches from controlled, low-density grazing for achieving defined habitat targets to 're-wilding', where winter food availability effectively limits population size, is very variable (Reke et al., 2019). To date there is a relatively small scientific literature documenting these new grazing approaches to conservation management.

Perhaps the best documented project is at Oostvaardersplassen, a re-wilding project encompassing 5,600 ha on a former polder in the Netherlands, where Heck cattle (Bos taurus), Konik horses (Equus ferus caballus) and Red Deer (Cervus elaphus) were introduced during the 1980s and 1990s. Here grazing animal densities have been shown to influence transitions between stands of Phragmites australis and shrub development (Vulink et al., 2000), with increasing densities of grazing animals over time leading to the gradual destruction of woody species and low levels of sapling development (Smit et al., 2015; Cornelissen et al., 2014).
In 2018, high mortality rates due to starvation occurred in the populations of grazing animals at Oostvaardersplassen, leading to a public outcry (Teunissen, 2019). This demonstrated that where such projects are fenced and do not contain predator species, the dynamics are not fully naturalised and that some level of population control may be necessary.

In contrast, The Wicken Fen Vision (WFV) project in Cambridgeshire, UK $\left(52^{\circ} 18^{\prime} 24^{\prime \prime} \mathrm{N}\right.$, $0^{\circ} 16 ' 51$ 'E) is a landscape-scale habitat creation project on ex-arable land, that uses a naturalistic grazing system, with Highland cattle (Bos taurus) and Konik horses, but with a controlled maximum grazing density (Laidlaw, 2019). The WFV is adjacent to Wicken Fen National Nature Reserve (NNR) and both are owned by the National Trust (NT), a UK-based Non-Governmental Organisation. The NNR comprises an area of 256 ha of undrained alkaline fen and is a highly species-rich $(>9,000$ species of plants and animals), Ramsar designated wetland of international importance. All the land surrounding the core part of the NNR has been farmed intensively for arable crops since the 1950s although the bulk of the Fenland had been converted to agriculture by 1850 resulting in long-term drainage and wastage of peat soils.

The WFV was initiated in 1999 by the NT with the aim, over a 100-year period of converting 5,300 ha of drained and intensively farmed arable land into nature conservation land. This would, amongst other objectives, result in the expansion of suitable habitats for species currently restricted to the NNR, allow greater connectivity and space for wildlife, and achieve substantial reductions in the loss of peat soils and carbon emissions. The project currently covers 800 ha and natural regeneration, extensive grazing, and fluctuating, shallow water tables have contributed to the development of a changing mix of wetland and dryland habitats across this area (Stroh, 2012a). The project does not have target habitats and has adopted an open-ended approach to habitat outcomes (Hughes et al., 2011).

This study reports on the development of vegetation assemblages over an 11-year period (2007-2017) over part of the WFV.

The main aims were:

1. To compare changes in plant species composition and diversity between grazed and ungrazed areas across part of the WFV. 
Peter A. Stroh et Al. - The effects of extensive grazing on the Vegetation of a landsCape-SCALe Restoration Site

Table 1: Descriptions of the three areas that make up the study site.

\begin{tabular}{llll}
$\begin{array}{l}\text { Sub-section of } \\
\text { study site }\end{array}$ & Previous land use history & Soil characteristics & \multicolumn{1}{c}{$\begin{array}{c}\text { Year of } \\
\text { conversion } \\
\text { from arable }\end{array}$} \\
\hline $\begin{array}{l}\text { Adventurers } \\
\text { Fen } \\
(23.3 \mathrm{ha})\end{array}$ & $\begin{array}{l}\text { Drained and ploughed during World War II } \\
\text { for arable crops. Last crops taken in 1947. } \\
\text { Land returned to the National Trust in } \\
\text { 1953. Some peat wastage }\end{array}$ & $\begin{array}{l}\text { Peat depth 0.7-0.9 m, above } \\
\text { silty loam and gravel deposits } \\
\text { on Gault clay }\end{array}$ & 1953 \\
\hline $\begin{array}{l}\text { Bakers Fen } \\
\text { (50.4ha) }\end{array}$ & $\begin{array}{l}\text { Drainage and intensive arable regime for a } \\
\text { continuous period of }>70 \text { years, leading to } \\
\text { substantial peat wastage }\end{array}$ & $\begin{array}{l}\text { Peat depth 0.3-0.4 m, peat } \\
\text { mixed with silt and gravel de- } \\
\text { posits above the Gault clay }\end{array}$ & \multirow{2}{*}{1993} \\
\hline $\begin{array}{l}\text { Guinea Hall } \\
\text { (45.4ha) }\end{array}$ & $\begin{array}{l}\text { An orchard until the 1940s, then }>50 \text { years } \\
\text { of continuous arable crops }\end{array}$ & $\begin{array}{l}\text { Drier site with degraded peats } \\
\text { (0.15-0.25m) mixed with un- } \\
\text { derlying clays and chalk }\end{array}$ & 2000 \\
\hline
\end{tabular}

2. To explore differences in plant composition using plant species traits and plant- environment associations.

3. To examine changes in vegetation structure across the WFV using a remote-sensing approach.

4. To examine the influence of land use histories on grazing outcomes in different parts of the site.

\section{MethodS}

\section{Study site}

The study site includes a part of Wicken Fen NNR that was briefly drained during the 1940s (Adventurers' Fen) and parts of the WFV (Baker's Fen, Guinea Hall), all forming a single continuous grazing unit of 119 ha, any part of which can be accessed at any time by the grazing animals that live there. Dif- ferent parts of the study site vary in terms of previous land use history, water table depths, soil profiles and number of years since conversion from arable agriculture (Table 1).

Adventurer's Fen has the greatest depth of remaining peat and the lowest summer water tables $(<0.8 \mathrm{~m})$ compared with the former arable areas, though all areas show considerable inter-annual variation. For example, 2012 was a year of intense rainfall events and all parts of the study site had high summer water tables $(<0.5 \mathrm{~m}$ depth on Adventurers Fen, Figure 1) whereas 2011 was a dry year with particularly low summer water tables across much of the site (close to $1.5 \mathrm{~m}$ depth on Bakers Fen, Figure 1).

Average annual rainfall for the area is $530 \mathrm{~mm}$ but is exceeded by average annual potential evapotranspiration (594 mm) (McCartney \& de la Hera,

047-2(DL) Adventurers Fen/Water Level

107-1(DL) Bakers Fen/Water Level

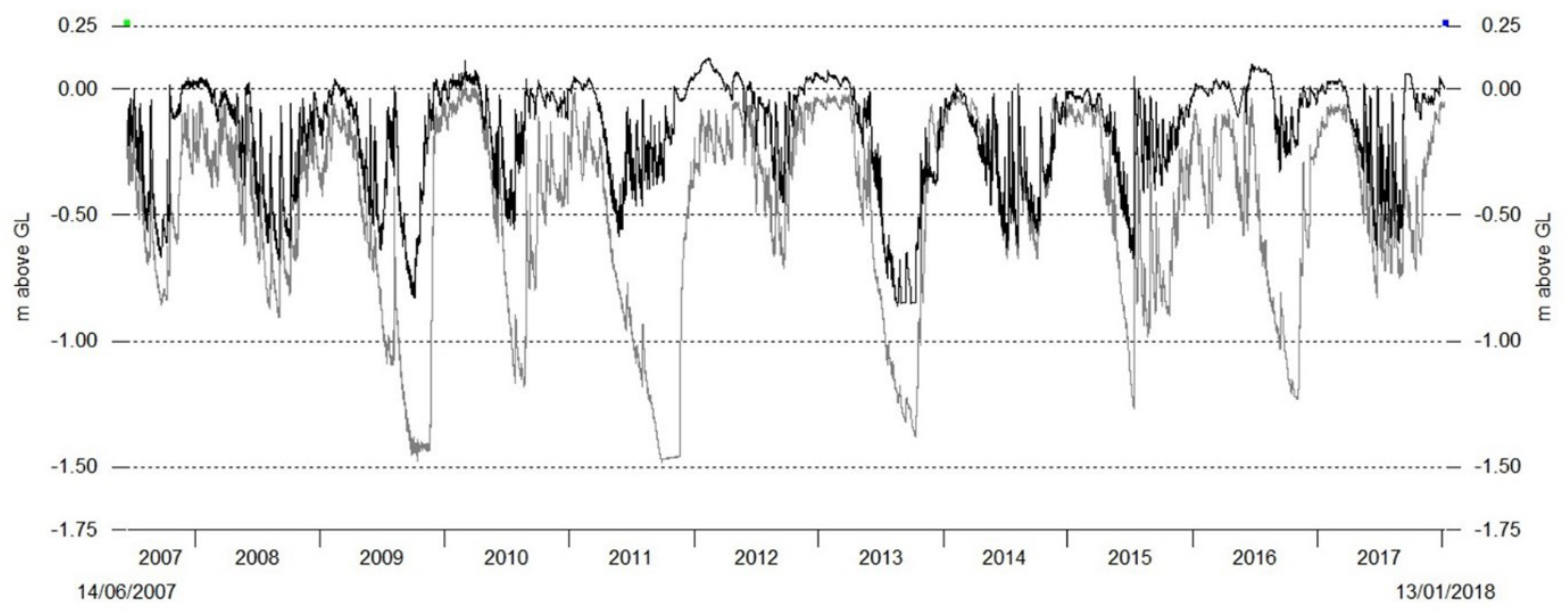

Figure 1: Water table levels below the ground surface from two sites within the study area. Adventurers' Fen has relatively deep peats $(0.7-0.9 \mathrm{~m})$, Baker's Fen has shallow degraded peats $(0.3-0.4 \mathrm{~m})$ underlain by silts and clay. 
2004). Departures from the mean annual temperatures, numbers of air frost days and precipitation for a 30-year baseline period August 1980-July 2010 were calculated for the 12 months (August to July) prior to vegetation recording for each year, using data from the meteorological station at NIAB in Cambridge, 16 $\mathrm{km}$ to the SW of the study site. During the 11 years of the study period, eight years had higher than average temperatures (a mean of $+0.69^{\circ} \mathrm{C}$ per year), seven years had higher than average numbers of frostfree days (a mean of +13 frost free days per year) and seven years had less than average precipitation (a mean of $-46 \mathrm{~mm}$ per year).

\section{The grazing system}

During the study period (2007-2017), livestock numbers on the study site fluctuated from a high in 2012 of 76 animals (59 horses, 17 cattle $(0.64$ head/ ha)) to a low in 2013 of 36 animals ( 28 horses, 8 cattle $(0.3$ head/ha)) (Figure 2).

At the WFV, although it is the intention to have a fluctuating grazing ratio, the upper limit of that ratio is currently set at a cautious 0.53 head/ha on a yearround grazing basis. This is well within the range for medium level stocking rates recommended for wet mesotrophic grasslands (Lane, 1992) and very similar to the grazing densities maintained at other European grazed wetland restoration sites (e.g. Mann
\& Tischew, 2010). When grazing densities exceed this level, animals are removed from the system and taken to new sites within the WFV or to other nature reserves. This happened in 2013 when the number of animals was reduced from 76 to 36 . The site is also frequented by wild deer, especially Roe deer (Capreolus capreolus). The first grazing animals (13 horses and 9 cattle) were introduced gradually to part of the study site between 2003 and 2005. In 2006, Adventurers Fen and Bakers Fen were linked up and in 2008 Guinea Hall was added, so that by 2008 the animals could roam freely across the whole study site.

\section{Vegetation sampling}

To monitor the effect of this grazing, seven 25 $\mathrm{m} \times 25 \mathrm{~m}$ fenced exclosures were erected across the study site in late 2006. Locations avoided the wettest parts of the study site, where there was standing water in winter and spring. Fencing prevents horses, cattle and deer, but not smaller mammals, from entering the exclosures. At each exclosure location, two pairs of fixed quadrats were recorded, one pair inside and one pair outside the exclosure. The outside pair was $5 \mathrm{~m}$ from the exclosure edge. This means that twenty-eight quadrats were recorded in each year of data collection. Paired quadrats were equidistant from the nearest ditches to reduce confounding hydrological variables since ditches influence water

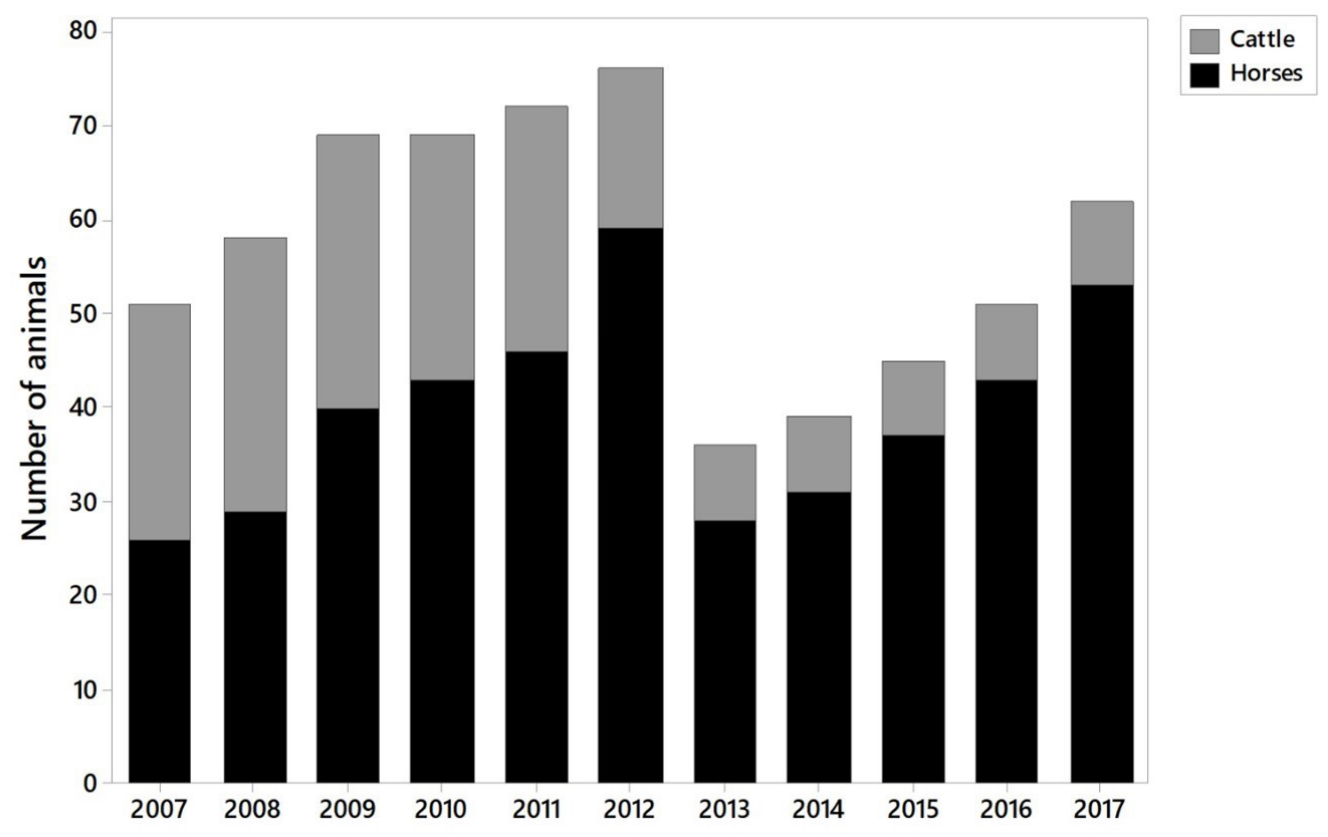

Figure 2: Numbers of grazing animals during the study period from 2007 to 2017. 
tables. Recording took place once, in mid-June each year.

The percentage cover of all vascular plant species and leaf litter was recorded from the twenty-eight vegetation quadrats in nine out of 11 growing seasons between 2007 and 2017 (no data in 2015, 2016 due to lack of personnel). Vegetation height data were collected from 2013 onwards. Taxonomy follows Stace (2010).

\section{Plant functional traits and environmental associations}

Plant functional traits are a valuable tool for understanding vegetation distribution across heterogeneous areas (Schaffers \& Sykora, 2000) as individual species are often restricted in distribution whereas traits are widespread (Pakeman, 2004). Canopy height and Competitor-Stress-Tolerator-Ruderal (C-S-R, sensu Grime, 1974) were chosen, the latter being growth strategies that integrate across a number of traits. Values followed Hodgson et al. (1995). Ellenberg values are widely used in ecology for a semi-quantitative description of plant species' environmental requirements (Garnier et al., 2017). Inferred Ellenberg L (light), Ellenberg F (moisture) and Ellenberg N (fertility) values were from PLANTATT (Hill et al., 2004). C-S-R traits were based on the 69 most common species with values in Grime et al. (2007). For each of these measures, weighted mean values for each quadrat in each year were calculated using species percentage cover as weights.

\section{Vegetation analyses}

The plant species cover data for the 28 quadrats in each of the 9 years of data collection (252 quadrat data sets in total) were subjected to Detrended Correspondence Analysis (DCA) in the CANOCO 5 package. Prior to analysis, data were $\log (\mathrm{x}+1)$ transformed and the down-weighting of rare species option was selected. The use of DCA over Correspondence Analysis was justified since the length of the longest gradient was 4.56. Centroids of each grazing treatment in each year were calculated from the averages of the relevant 14 values on the first and second DCA axes.

Species richness was calculated as the mean number of species per quadrat recorded in each year. Cumulative species richness was calculated as the total number of species recorded in that quadrat since the start of records in 2007.

Repeated measures ANOVA was used to analyse data on species richness, cumulative species richness, litter, cover weighted scores for Ellenberg L, Ellenberg F, Ellenberg N, Canopy Height Score, Competitor, Stress Tolerator and Ruderal and for DCA1 and DCA2 scores. This analysis was based on a randomised block design of 14 pairs of two grazing treatments with the nine-yearly records representing the repeated measures. Analysis was undertaken in the SPSS 24 package using Greenhouse Geisser adjustments to degrees of freedom. The significance of grazing treatment was assessed by $\mathrm{F}$ tests with 1 and 13 d.f.; that for Year and Year*grazing treatment (maximally) on 8 and 104 d.f. However, our focus on Year and Year interaction effects was intended to only examine the linear year component in order to assess for trends over time, rather than unspecified year-to-year changes. Repeated measures ANOVA was also undertaken for the three years $(2012,2014$, 2017) of height measurement data, and for all years for the ten most common species.

Other data manipulation, analyses and graph production were carried out in Minitab 18.

\section{Remote sensing of vegetation at the WFV}

In 2007 and 2012 False Colour Infrared (FCIR) aerial photographs with a nominal spatial resolution of $20 \mathrm{~cm}$ were flown across the WFV area to obtain a broader picture of vegetation change between the two points in time. Ground reference data were collected in a series of additional quadrats across the WFV and combined with field mapping to develop labels and describe categories of vegetation structure seen in the images. An object-based interpretation of the FCIR images was used to obtain representative land parcels and habitat patches using image segmentation. This was combined with the objectivity of an 'unsupervised' classification of the individual pixels and a subsequent supervised labelling of the resulting spectral clusters to 'scene components' using field data and mapping for each year.

The FCIR-derived results from 2012 were used to carry out an analysis of five of the seven exclosures in the study area. Data from the area inside the five exclosures were compared with data from within nearby ungrazed $25 \mathrm{~m} \times 25 \mathrm{~m}$ areas that were deliberately not near to boundary features, to analyse differences in vegetation structure. An analysis of a larger section of the WFV area (257 ha) was carried out to get a broader quantification of change in vegetation structure between 2007 and 2012.

In addition, an analysis of change in heterogeneity across the site between 2007 and 2012 was carried out by calculating an indicator for each of the 121 
land parcels. The heterogeneity was estimated from a measure of relative entropy calculated on the scene component proportions which is zero for a totally uniform feature (only one scene component) and 1 for the maximum level of scene component mixing.

\section{RESULTS}

\section{Vegetation changes over time (2007-2017)}

(i) Plant composition

A total of 86 plant species was found across all quadrats and years. The first two axes of the DCA accounted for $15.6 \%$ and $8.3 \%$ of the variation in the species data (species score plot, Figure 3; treat- ment centroids/year, Figure 4). Axis 1 in Figure 3 is related to moisture with species typical of wetter conditions on the left side of the plot (e.g. Eupatorium cannabinum, Juncus inflexus) and of drier conditions to the right (e.g. Phleum bertolonii, Prunella vulgaris). Axis 2 is related to grazing intensity with species typical of low intensity grazing at the bottom (e.g. Anthriscus sylvestris, Epilobium hirsutum, Phragmites australis) and of higher intensity grazing at the top of the plot (e.g. Cynosurus cristatus, Medicago lupulina) - some species of more open swards are also found nearer the top of the plot e.g. Bidens tripartita.

Figure 4 suggests that the vegetation communi-

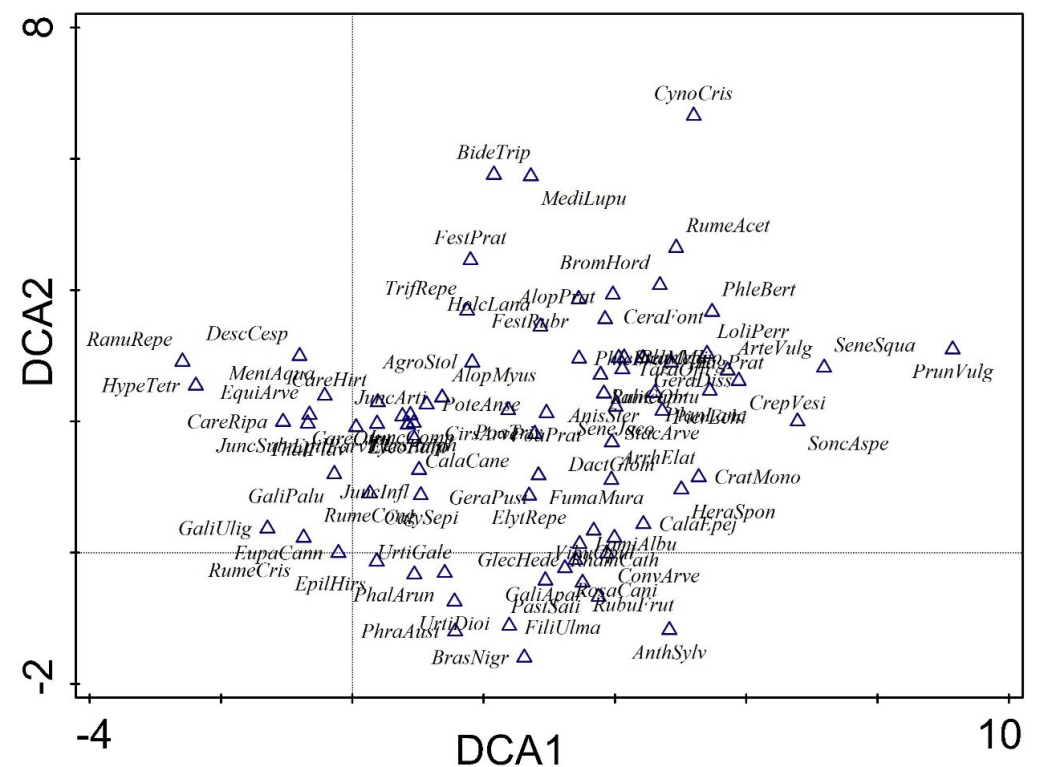

Figure 3: Detrended Correspondence Analysis (DCA) ordination of plant species cover data showing species abbreviations (some labels have been moved slightly to improve clarity). All species listed with full names in Appendix 1.

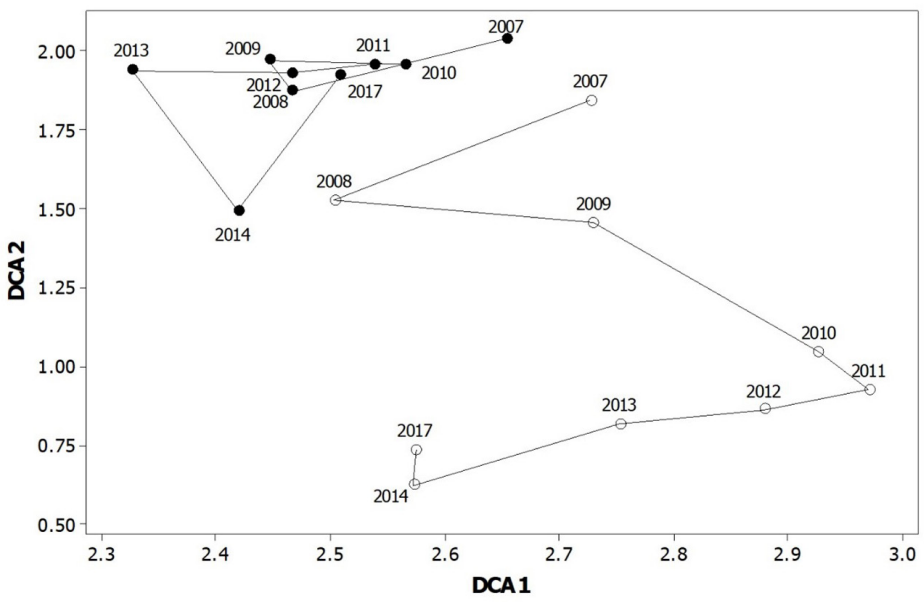

Figure 4: Detrended Correspondence Analysis (DCA) ordination of plant species cover data showing centroids of grazed (solid symbol) and ungrazed (open symbol) quadrats in each year. 
ties within the grazed quadrats have remained more consistent than those within the ungrazed quadrats. In part this may reflect the late start of monitoring at the site and the fact that some change in the grazed areas had happened before monitoring began. Repeated Measures ANOVA of the first and second axes scores (Table 2) reveals significant differences between treatments on both axes $(\mathrm{p}=0.023$ for DCA1 and $\mathrm{p}<0.001$ for DCA2). A significant result for the interaction between Year and grazing treatments on DCA2 $(p<0.001)$ suggests continued divergence of the two grazing treatments over time.

Annual mean species richness varied little in grazed quadrats but decreased in ungrazed quadrats (Figure 5), with significant changes over time, significant differences between treatments and significant interactions between the two (Table 2). Cumulative species richness also showed a significant change through time and in trajectories of change (interaction), though not between treatments (Figure 5, Table 2).

Table 2: Significance from Repeated Measures ANOVA for changes over time (P (Year Linear)), differences between Ungrazed and Grazed treatments (P (Grazing)), and divergence/convergence of Ungrazed and Grazed treatments over time $(\mathrm{P}(\mathrm{Y}$ Linear* $\mathrm{G}))$. Significant results shown in bold.

\begin{tabular}{llll} 
& $\mathrm{P}$ (Year Linear) & $\mathrm{P}$ (Grazing) & $\mathrm{P}(\mathrm{Y}$ Linear*G) \\
\hline Species Richness & $\mathbf{0 . 0 3 2}$ & $\mathbf{0 . 0 0 3}$ & $\mathbf{0 . 0 0 2}$ \\
Cumulative Species Richness & $<\mathbf{0 . 0 0 1}$ & 0.971 & $\mathbf{0 . 0 3 1}$ \\
Ellenberg L (Light) & $<\mathbf{0 . 0 0 1}$ & $\mathbf{0 . 0 0 5}$ & $<\mathbf{0 . 0 0 1}$ \\
Ellenberg F (Moisture) & $\mathbf{0 . 0 0 4}$ & 0.358 & 0.866 \\
Ellenberg N (Nutrient) & $\mathbf{0 . 0 2 3}$ & $<\mathbf{0 . 0 0 1}$ & $\mathbf{0 . 0 1 6}$ \\
Height Score & $\mathbf{0 . 0 0 1}$ & $<\mathbf{0 . 0 0 1}$ & $\mathbf{0 . 0 4 3}$ \\
Height cm (2013-2017) & 0.899 & $<\mathbf{0 . 0 0 1}$ & 0.490 \\
Litter & $<\mathbf{0 . 0 0 1}$ & $<\mathbf{0 . 0 0 1}$ & 0.367 \\
Competitor & $\mathbf{0 . 0 2 7}$ & $\mathbf{0 . 0 0 1}$ & $\mathbf{0 . 0 2 5}$ \\
& & & \\
Stress Tolerator & 0.609 & 0.522 & 0.318 \\
Ruderal & $\mathbf{0 . 0 0 8}$ & $\mathbf{0 . 0 0 1}$ & $\mathbf{0 . 0 3 6}$ \\
DCA1 & 0.157 & $\mathbf{0 . 0 2 3}$ & 0.513 \\
DCA2 & $<\mathbf{0 . 0 0 1}$ & $<\mathbf{0 . 0 0 1}$ & $<\mathbf{0 . 0 0 1}$
\end{tabular}

Species in more than $25 \%$ of quadrats ( $\mathrm{n}=10$ species)

\begin{tabular}{llll}
\hline Agrostis stolonifera & 0.657 & $<\mathbf{0 . 0 0 1}$ & $\mathbf{0 . 0 0 1}$ \\
Arrhenatherum elatius & 0.656 & $\mathbf{0 . 0 3 7}$ & 0.657 \\
Calystegia sepium & $\mathbf{0 . 0 2 3}$ & 0.223 & 0.384 \\
Cirsium arvense & $\mathbf{0 . 0 0 1}$ & 0.676 & 0.755 \\
Dactylis glomerata & $\mathbf{0 . 0 2 9}$ & $\mathbf{0 . 0 2 6}$ & 0.972 \\
Elytrigia repens & 0.378 & 0.662 & 0.760 \\
Festuca rubra & 0.069 & 0.935 & 0.127 \\
Heracleum sphondylium & 0.474 & $\mathbf{0 . 0 1 3}$ & 0.776 \\
Holcus lanatus & $\mathbf{0 . 0 2 1}$ & $\mathbf{0 . 0 1 9}$ & 0.184 \\
Poa trivialis & $<\mathbf{0 . 0 0 1}$ & $<\mathbf{0 . 0 0 1}$ & $\mathbf{0 . 0 1 9}$ \\
& & & \\
Species in 10-25\% of quadrats (n=12 species) & $\mathbf{0 . 0 1 0}$ & 0.922 & 0.267 \\
\hline Bromus hordeaceus & $\mathbf{0 . 0 4 3}$ & $\mathbf{0 . 0 2 8}$ & 0.314 \\
Calamagrostis epigejos & 0.077 & 0.071 & 0.354 \\
Carex hirta & $\mathbf{0 . 0 0 5}$ & 0.086 & 0.248 \\
Carex otrubae & 0.143 & 0.085 & 0.096 \\
Epilobium hirsutum & $\mathbf{0 . 0 2 9}$ & $\mathbf{0 . 0 0 4}$ & $\mathbf{0 . 0 3 1}$ \\
Galium aparine & 0.189 & $\mathbf{0 . 0 4 7}$ & 0.152 \\
Glechoma hederacea & 0.687 & 0.275 & 0.101 \\
Juncus inflexus & 0.876 & 0.430 & 0.182 \\
Juncus subnodulosus & 0.096 & 0.650 & 0.187 \\
Persicaria amphibia & $<\mathbf{0 . 0 0 1}$ & 0.492 & $\mathbf{0 . 0 2 0}$ \\
Phalaris arundinacea & 0.084 & $\mathbf{0 . 0 3 0}$ & 0.099 \\
Urtica dioica &
\end{tabular}




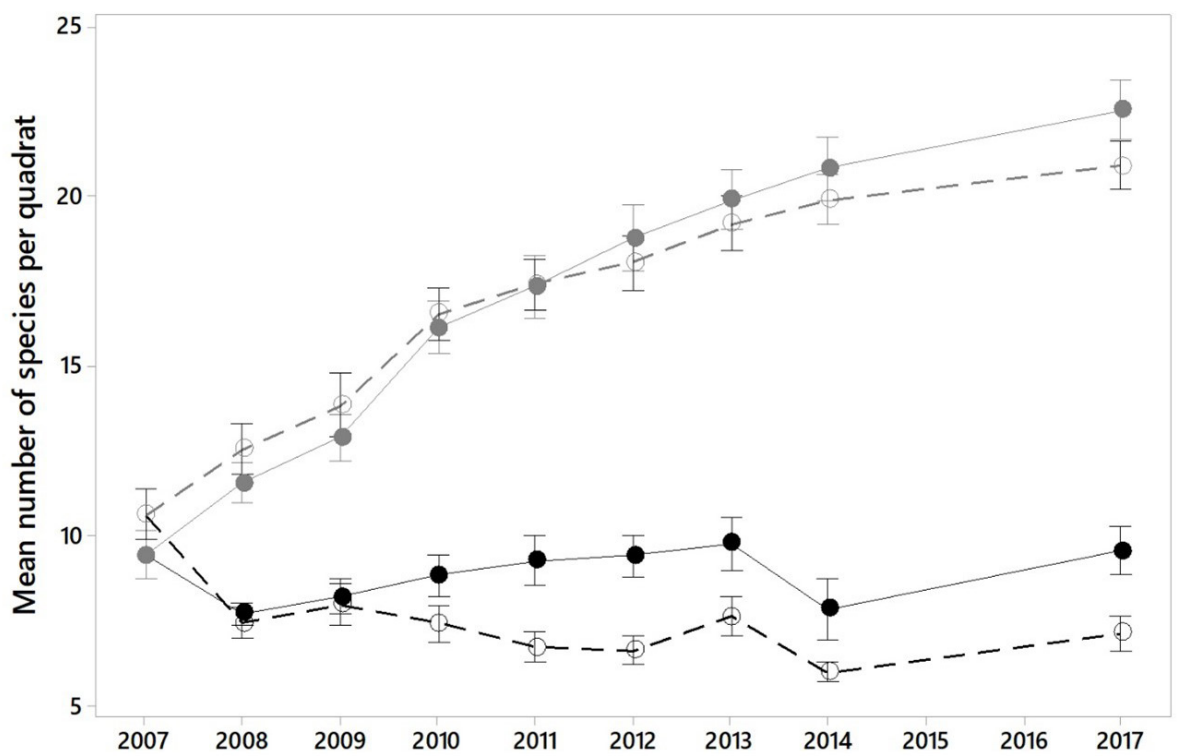

Figure 5: Cumulative species richness across years (mean of 14 quadrats $\pm \mathrm{SE}$ )(grey dashed line - ungrazed; grey solid line - grazed); number of species per year (mean of 14 quadrats $\pm \mathrm{SE}$ ) (black dashed line - ungrazed; black solid line - grazed).

(iii) Plant functional traits and environmental associations

Significant divergence between treatments was identified for Ellenberg L (Figure 6, Table 2) and Ellenberg N (Figure 7, Table 2). Cover of nitrogen-loving plants decreased in value under grazing, with this decrease perhaps related to a complex interaction between disturbance, the recruitment of additional taxa with relatively low Ellenberg $\mathrm{N}$ values over time, and the nitrogen status of the soil. It should, however, be noted that the use of Ellenberg indicator values, while a convenient means of summarising trends and impacts, must be exercised with caution. Few species have their behaviour perfectly defined by these values, not least because of genetic variation within each species to which the presence of agricultural cultivars in this habitat must be added. Species with an at least partially ruderal strategy may react positively both to increased fertility and to disturbance of the soil, and it is not always possible to distinguish these reactions. Nonetheless, focussing on $\mathrm{mN}$ (the mean fertility indicator value, especially when cover-weighted) for species showing significant increases and declines in cover/abundance will allow inferences to be made that are not unduly swayed by the trend in one species.

Ellenberg Moisture scores suggested a general wetting of the whole site through the study period. The canopy height score showed significant differences between all three analysed terms (Table 2).
Field measurements in 2017 showed an average of $28 \mathrm{~cm}$ height in grazed quadrats (highest mean 47 $\mathrm{cm}$ ) and $75 \mathrm{~cm}$ in ungrazed quadrats (highest mean $200 \mathrm{~cm}$ ). Height measurements were carried out from 2013 onwards and in this shorter data period a significant difference in height was registered between grazed and ungrazed quadrats (Table 2). Litter increased significantly over time and was significantly greater in ungrazed treatments (Table 2).

Over the 11 years of monitoring, several species have spread within the grazed swards, notably Agrostis stolonifera, Heracleum sphondylium and Juncus subnodulosus, whilst Bromus hordeaceus and Cirsium arvense have declined. Trends in the ungrazed sward are similar for $B$. hordeaceus, $C$. arvense and H. sphondylium. Calamagrostis epigejos, Epilobium hirsutum, Galium aparine and Urtica dioica have also increased in the ungrazed sward since 2007, whereas the mean cover of Carex hirta, C. otrubae, Festuca rubra and Holcus lanatus has reduced.

Of the 10 plant species that were present in more than a quarter of all quadrats, seven were graminoids, and five of these (A. stolonifera, Arrhenatherum elatius, Dactylis glomerata, $H$. lanatus and P. trivialis) had a significantly greater abundance within the ungrazed exclosures (Table 2). Two forbs (H. sphondylium and Persicaria amphibia) were significantly commoner in ungrazed exclosures than in grazed swards. Agrostis stolonifera, Dactylis glomerata, Festuca rubra, Poa trivialis and Juncus spp. showed 


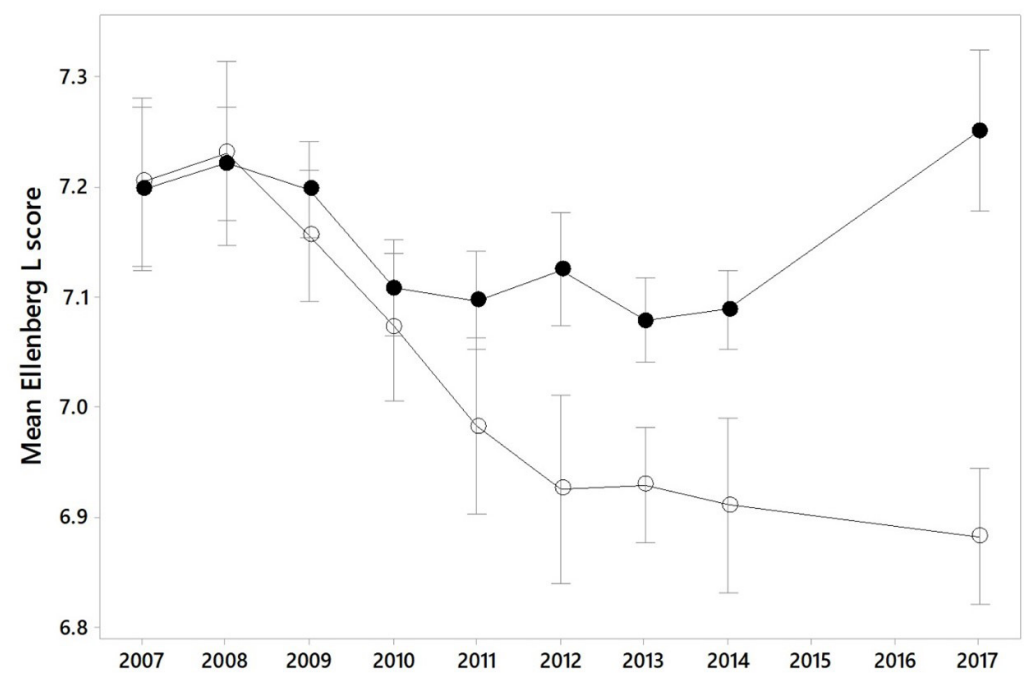

Figure 6: Mean $( \pm \mathrm{SE})$ cover-weighted Ellenberg Light score per quadrat for grazed (solid symbol) and ungrazed (open symbol) quadrats.

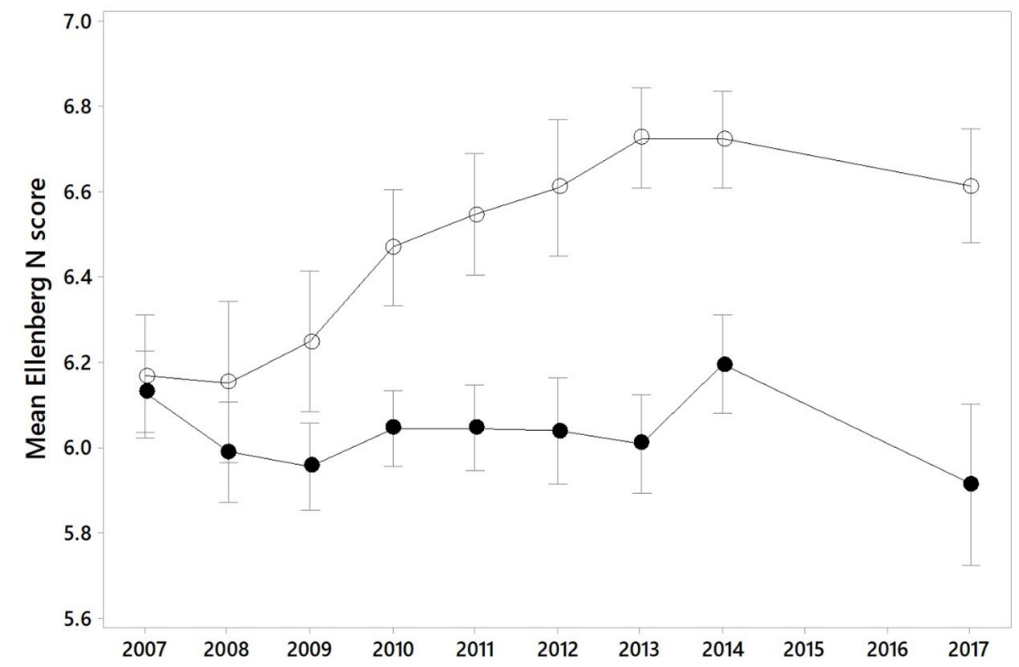

Figure 7: Mean $( \pm \mathrm{SE})$ cover-weighted Ellenberg $N$ (fertility) score per quadrat for grazed (solid symbol) and ungrazed (open symbol) quadrats.

a preference for grazed swards. Cirsium arvense, Carex spp. and Glechoma hederacea also showed a preference for grazed swards but less marked.

By 2017 there were clear differences in the adaptive strategies (sensu Grime 2006) between the species assemblages in the grazed and ungrazed areas (Figure 8). The grazed swards had higher values of both stress-tolerators and ruderals, although only the latter measure was significantly different to the ungrazed exclosures. The ungrazed areas had a significantly greater cover of competitors.

\section{Vegetation differences between sub-sections of the study site}

There was a clear separation between Adventurer's Fen vegetation and the other two parts of the study area along axis 1 of the DCA (Figure 9), and some separation between Guinea Hall and Bakers Fen along axis 2. The species data from Figure 3 suggest that Adventurers' Fen is wetter than the other two parts of the study site.

The two exclosures on Adventurers' Fen were characterised by tall, dense herb and grass vegetation including Phalaris arundinacea, Epilobium hirsu- 


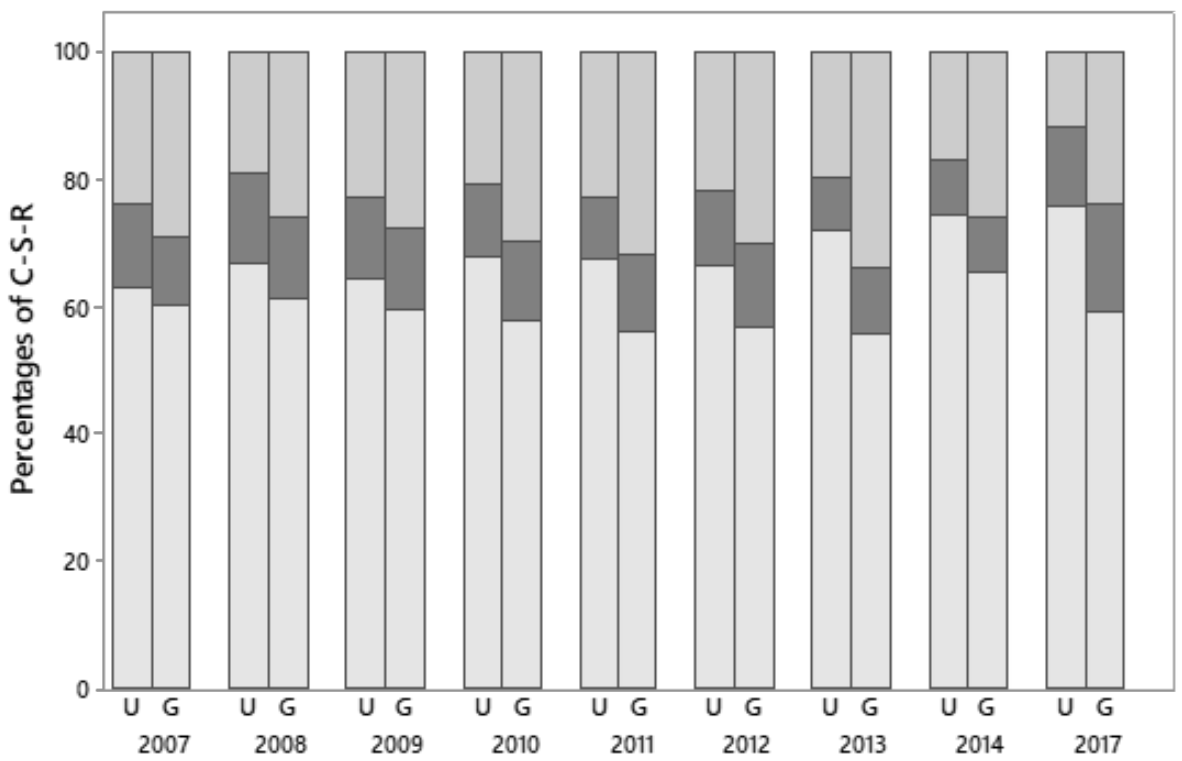

Figure 8. Progression of Competitor (pale grey), Stress Tolerator (dark grey) and Ruderal (medium grey) traits across years in Ungrazed (U) and Grazed (G) plots.

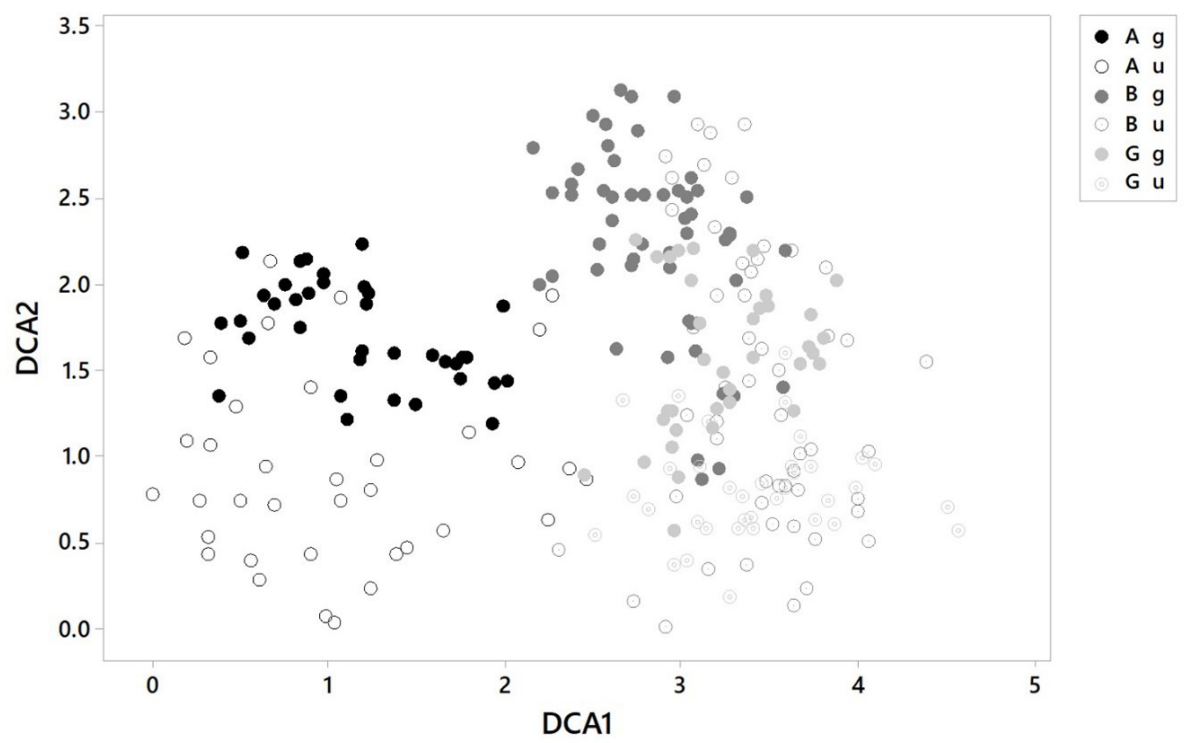

Figure 9: DCA showing separation between grazed $(\mathrm{g})$ and ungrazed $(\mathrm{u})$ quadrats on Adventurers Fen (A) on the left and the quadrats on Bakers Fen (B) and Guinea Hall (G) on the right.

tum, Urtica dioica subsp. galeopsifolia and Juncus inflexus and an absence of scrub. Similar species were found outside these exclosures but the vegetation height was shorter. Guinea Hall plant communities are mostly species of semi-improved or improved neutral grassland, dominated by Elytrigia repens, Arrhenatherum elatius and Dactylis glomerata outside the exclosures, with substantial bushes of Rubus fruticosus, Crataegus monogyna and Rhamnus cathartica inside one of the two exclosures on that part of the study site. Only one of the three ex- closures on Bakers Fen had substantial scrub vegetation (Rhamnus cathartica, Crataegus monogyna) during the study period.

\section{Changes in vegetation structure using FCIR imagery}

The 2012 FCIR imagery showed that two of the five exclosures, Guinea Hall 110 and Baker's Fen 107 had increased scrub growth inside the exclosure compared with the grazed area of equivalent size outside (Figure 10). In two other exclosures, Adven- 


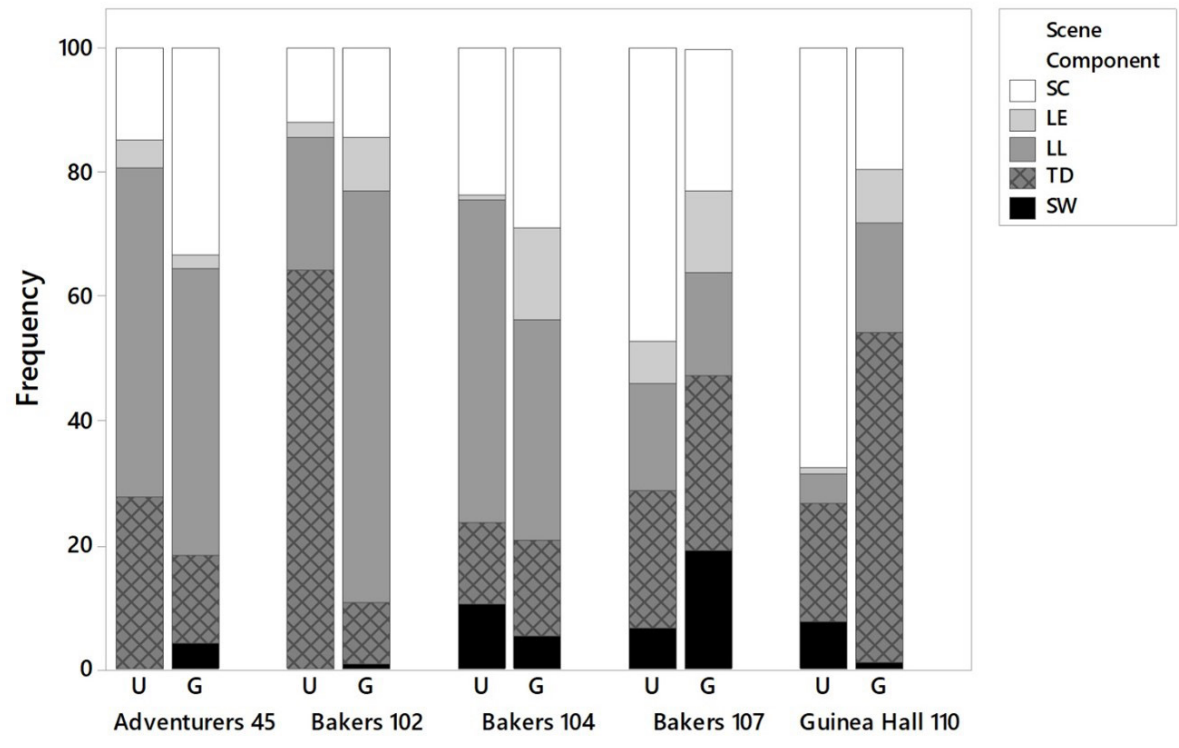

Figure 10: Comparison of scene components derived from analysis of FCIR aerial photography inside (U) and outside $(\mathrm{G}) 5$ grazing exclosures in 2012. Key: SW Seasonally wet drawdown zones; TD Tall, dense non-woody vegetation; LL Late season, short grassland vegetation; LE Dry, early season short grassland vegetation; SC Scrub. No Open Water or Bare Ground categories were recorded.

turers Fen 45 and Baker's Fen 102, the area inside the exclosure shows much taller grassland than the grazed area outside. In Baker's Fen 104, the difference between the inside and outside of the exclosure shows little difference on the FCIR imagery, though on the ground the grassland vegetation was taller inside the exclosure than outside.

Analysis of a 257 ha area of the WFV using FCIR imagery showed that scrub increased in area from 5\% in 2007 to just over $25 \%$ in 2012 . The heterogeneity indicator increased in value in 100 of the 121 land parcels assessed in both 2007 and 2012.

\section{Discussion}

\section{Vegetation change over time}

Our results show that cumulative species richness on the ex-arable land, after nearly 20 years of natural regeneration, is increasing in grazed compared with ungrazed areas. This is a similar finding to that of van Klink \& Smit (2016) who reported decreasing plant species richness in ungrazed areas compared with grazed areas at Oostvaardersplassen.

Overall richness across the study site is higher than this study shows because species restricted to the wettest parts of the study site e.g. ditches and pools, were not included within the grazing experiment. Our study recorded a total of 86 vascular plant species which is much lower than many semi-natural grassland areas in other parts of Europe, for example 189 species in the grassland areas of Polesie National Park in Poland (Rysiak et al., 2021). The undrained Wicken Fen NNR is also substantially richer with 288 vascular plant species. The lower species richness and lack of rare species at the WFV is not surprising, as the starting point for habitat development on the WFV was a set of structurally damaged peat soils, with high residual nutrient and agri-chemical loadings. There has never been any expectation that the study site could mirror the adjacent undrained nature reserve or the diversity of long established semi-natural grasslands elsewhere. Instead, novel, mixed vegetation assemblages with elements of typical fen vegetation were expected (Hughes et al., 2011) and this study has found such assemblages to be developing.

Changing animal numbers during the study period are likely to have had an impact on the annual survey results. Thus in 2013, grazing animal densities were at their lowest with only 36 grazing animals compared with 76 in 2012. This may also explain the higher levels of litter found in 2014 in all grazed quadrats compared with previous years, an association also noted by Vulink et al. (2000) at Oostvaardersplassen.

The presence or absence of scrub inside exclosures is most likely explained by random seed deposition events, although relationships between 
non-random and random factors in long-distance seed dispersal remain difficult to elucidate (Soons \& Bullock, 2008). On Guinea Hall, the two grazing exclosures were only $50 \mathrm{~m}$ apart and yet one grew scrub and the other did not, despite having similar soils and water tables. A study of endozoochorous seed dispersal by grazing animals on part of Wicken Fen NNR showed that seeds of at least one third of the background population of available plant species could survive ingestion, and that animals had the ability to transport hundreds of thousands of seeds, mostly graminoids, during the course of one year (Stroh et al., 2012b).

\section{Vegetation differences across the study site}

Interpretation of the results of the grazing quadrats is complicated by the variability in water tables, soil profiles and previous land-use histories across the study site. A study of the relationships between vegetation and soil hydrology as quantified by the Sum Exceedance Values (SEV) across parts of the WFV showed that soil hydrology was a helpful explanatory factor in understanding vegetation development (Stroh et al., 2013), with differences largely related to previous management histories. In addition, soil seed banks in different parts of the study site were very variable, with many species found exclusively within areas of similar land use history (Stroh et al., 2012a). Studies elsewhere have also shown that over decadel time periods, changes in the species composition of semi-natural grasslands are very variable and depend on soil hydrology, soil fertility and withdrawal or increase of grazing or mowing regimes (Kulik et al., 2017; Kurek et al., 2016).

Adventurers' Fen has a different history from the other two areas, with only a short period under cultivation (Table 1) and a much longer period under restoration. It has been naturally regenerating since 1947 from the soil seed bank and colonisation by plants which survived in ditch boundaries (Stroh et al., 2012a). Because it was only drained for a limited period it retained significant depths of peat and has higher summer water tables then the other two areas (Figure 1). Species typical of fen plant communities are found across Adventurers' Fen, for example $G a$ lium palustre, Eupatorium cannabinum, Phragmites australis, Phalaris arundinacea and a variety of species of Juncus and Carex (Mountford \& Sparks, 2019) and many of these species were present in the recorded quadrats.
Baker's Fen and Guinea Hall have quite different vegetation communities from Adventurer's Fen with more species typical of drier grasslands and less fen species. This reflects the fact that both areas have much shorter histories of natural regeneration and longer histories of previous drainage and arable use than Adventurers' Fen (Table 1). Guinea Hall is overall much drier than the other two parts of the site with dipwell measurements during the period 20072012 showing summer water tables falling $1.5 \mathrm{~m}$ below ground level while winter levels rarely reached above ground. In different locations across the WFV study site, the species present inside and outside the exclosures varied considerably, with some exclusive to the quadrats in one area (e.g. Carex riparia on Adventurers' Fen) and others found across the study site (e.g. Agrostis stolonifera). The use of plant traits has been useful in helping to override edaphic variability across the study site in order to understand the impact of grazing better. Species inside grazing exclosures tend to be associated with shady conditions and higher soil nutrient levels, while outside the grazing exclosures, the opposite holds true. Within the ungrazed exclosures, the vegetation has become a mixture of coarse grasses (e.g. Arrhenatherum elatius and Elytrigia repens), species that are typically more nitrophilous (Galium aparine, Heracleum sphondylium and Urtica dioica) and competitive species characteristic of degraded tall-herb fen (Calamagrostis epigejos, Epilobium hirsutum and Phalaris arundinacea) and seedlings of shrubs. The vegetation in the grazed fields has become a closed sward dominated by low tillering grasses (Agrostis stolonifera, Dactylis glomerata, Festuca rubra, Holcus lanatus and Poa trivialis) and other graminoids including increased representation of Carex and Juncus species e.g. Carex hirta, C. otrubae, Juncus inflexus and J. subnodulosus). The grazed swards that have developed outside the exclosures are therefore, at present, moist mesotrophic grasslands with some elements of both rush-pastures and of inundation grasslands, but still clearly influenced by their agricultural past. Where grazing animals spend time, the sward becomes more disturbed with areas of open ground allowing more ruderal species to colonise. Inside exclosures on Adventurers Fen a tall-herb fen vegetation has developed with Epilobium hirsutum, Phalaris arundinacea and Urtica dioica subsp. galeopsifolia as common species while within the exclosures in the other two studied areas of the WFV, Arrhenatherum 
elatius and Calamagrostis epigejos are common grass species frequently accompanied by shrubs such as Crataegus monogyna and coarse herbs such as $U r$ tica dioica and Cirsium arvense.

A detailed study of the behaviour of the WFV grazing animals, who form their own social groups, revealed that cattle and horses rarely, if ever, occupy the same compartment simultaneously, though both move around almost all the site (Laidlaw, 2019). Within the context of landscape scale habitat creation, the variation in intensity, timing and length of grazing impacts in different locations is likely to contribute to a higher heterogeneity of plant communities across the site. Comparison of the FCIR images in 2007 and 2012 showed an increase in a calculated heterogeneity indicator in 100 of the 121 analysed land parcels.

\section{Conclusion}

This study is part of a more extensive monitoring programme across the WFV that is designed to be sustainable over the long term (Hughes et al., 2016). Although the small quadrat sample size in this study is not ideal for statistical analyses it has still been possible to detect significant trends over time and between treatments. No vegetation data were collected in 2015 or 2016 due to lack of personnel for the task, reflecting the difficulty of maintaining long-term monitoring programmes. The results show a gradual divergence of vegetation communities over an eleven-year period, between grazed and ungrazed areas of the low-density grazing used at the WFV but also considerable variations across the WFV site. The results suggest that decadal monitoring timeframes are important in understanding large scale, open-ended restoration projects because rates and directions of vegetation change are not rapid and, at local scale, are unpredictable. The difficulty of maintaining even quite basic vegetation monitoring suggests that monitoring programmes should keep data collection effort at manageable levels and frequencies, while still providing reliable data, so that they fit available budgets and monitoring skills.

\section{ACKNOWLEDGEMENTS}

Thanks to National Trust staff at Wicken Fen and Lesley Saint (Environment Agency) for their support over many years of monitoring. Monitoring (20072012) was funded by the Esmée Fairbairn Foundation (Grant nos. EN 06-2151, 09-2739). Charlotte Taylor assisted with data collection in 2013.

\section{REFERENCES}

Bakker, C., Blair, J. M. \& Knapp, A. K. (2003). Does resource availability, resource heterogeneity or species turnover mediate changes in plant species richness in grazed grasslands? Oecologia, 137, 385-391. https://doi.org/10.1007/ s00442-003-1360-y

Bakker, J. P. (1998). The impact of grazing on plant communities. In: Wallis de Vries, M. F., Bakker, J. P. \& S. Van Wieren (Eds.) Grazing as a tool in conservation management (pp. 137-184). London: Chapman and Hall.

Birks, H.J.B. (2005). Mind the gap: how open were European primeval forests? Trends in Ecology and Evolution, 20, 154-156.

Chaneton, E. J. \& Facelli, J. M. (1991). Disturbance effects on plant community diversity: Spatial scales and dominance hierarchies. Vegetatio, 93,143-156.

Colston, A. (2003). Beyond preservation: the challenge of ecological restoration. In: Adams, W. M. \& Mulligan, M. (Eds.), Decolonizing Nature: strategies for conservation in a post-colonial era (pp. 247-267). London: Earthscan.

Cornelissen, P., Gresnigt, M., Vermeulen, R., Bokdam, J., \& Smit, R. (2014). Transition of a Sambucus nigra L. dominated woody vegetation into grassland by a multi-species herbivore assemblage Journal for Nature Conservation, 22, 84-92. https://doi.org/10.1016/j.jnc.2013.09.004

Dormaar, J. F. \& Willems, W. D. (1998). Effect of forty-four years of grazing on fescue grassland soils. Journal of Range Management, 51,122126.

Garnier, E., Stahl, U., Laporte, M.-A., Kattge, J., Mougenot, I., Kühn, I., ... Klotz, S. (2017).

Towards a thesaurus of plant characteristics: An ecological contribution. Journal of Ecology, 105, 298-309. https://doi. org/10.1111/13652745.12698

Grime, J.P. (1974) Vegetation classification by reference to strategies. Nature, 250,26-31.

Grime, J.P., Hodgson, J.G. \& Hunt, R. (2007). (2 ${ }^{\text {nd }}$ edition). Comparative Plant Ecology. Castlepoint Press and BSBI.

Grime, J.P. (2006). Plant Strategies, Vegetation Processes, and Ecosystem Processes. Chichester: John Wiley and Sons Ltd.

Hill, M.O., Preston, C.D. \& Roy, D.B. (2004). PLANTATT. Attributes of British and Irish plants: status, size, life history, geography and 
Peter A. Stroh et Al. - The effects of extensive grazing on the Vegetation of a landsCape-SCALe Restoration Site

habitats. NERC Centre for Ecology and Hydrology, Monks Wood, Abbots Ripton, UK.

Hodgson, J.G., Grime, J.P., Hunt, R. \& Thompson, K. (1995). The Electronic Comparative Plant Ecology. London: Chapman and Hall.

Hughes, F. M. R., Colston, A. \& Mountford, J. O. (2005). Restoring riparian ecosystems: the challenge of accommodating variability and designing restoration trajectories. Ecology and Society, 10,1-12. https://www.ecologyandsociety.org/ vol10/iss1/art12/

Hughes, F.M.R., Stroh, P. A., Adams, W.A. Kirby, K. Mountford, J.O., \& Warrington, S. (2011). Monitoring and evaluating largescale, open-ended habitat creation projects: a journey rather than a destination. Journal for Nature Conservation, 19,245-253. http://dx. doi:10.1016/j.jnc.2011.02.003

Hughes, F.M.R., Adams, W.M., Butchart, S.H.M., Field, R.H., Peh, K.S.-H. \& Warrington, S. (2016). The challenges of integrating biodiversity and ecosystem services monitoring and evaluation at a landscape-scale wetland restoration project in the UK. Ecology and Society, 21(3),10. http://dx.doi.org/10.5751/ES-08616$\underline{210310}$

Huntly, N. J. (1991). Herbivores and the dynamics of communities and ecosystems. Annual Review of Ecology and Systematics, 22,477-503.

Kirby, K.J. \& Baker, A. (2013). The dynamics of pre-Neolithic landscapes and their relevance to modern conservation. In Rotherham, I.D. (Ed.) Trees, forested landscapes and grazing animals (pp.87-98). Abingdon: Routledge.

Kulik, M., Baryła, R., Urban, D., Grzywaczewski, G., Bochniak, A., Różycki, A., Tokarz, E., (2017). Vegetation and birds species changes in meadow habitats in polesie national park. East. Pol. Rocz. Ochr. Środowiska 19, 211-229.

Kurek, P., Steppa, R., Grzywaczewski, G., \& Tryjanowski, P. (2016). The silence of the lambs? Plant diversity in abandoned sheep pens. Plant, Soil and Environment, 62(1), 1-8.

Laidlaw, C. (2019). The behaviour of free-roaming herds of highland cattle and konik polski at Wicken Fen Nature Reserve. MPhil thesis, Anglia Ruskin University.

Lane, A. (1992). Practical Conservation: Grassland, Heaths and Moors. London: Hodder and Stoughton.
Lawton, J. H., P. N. M. Brotherton, V. K. Brown, C. Elphick, A. H. Fitter, J. Forshaw, R. W. Haddow, S. Hilborne, R. N. Leafe, G. M. Mace, M. P. Southgate, W. A. Sutherland, T. E. Tew, J. Varley \& Wynne, G. R. (2010). Making space for nature: a review of England's wildlife sites and ecological network. Report to Defra, UK Government.

Mann, S. \& Tischew, S. (2010). Role of megaherbivores in restoration of species-rich grasslands on former arable land in floodplains. Waldökologie, Landschaftsforschung und Naturschutz, 10, 7-15.

McCartney, M.P. \& de la Hera, A. (2004). Hydrological assessment for wetland conservation at Wicken Fen. Wetland Ecology and Management, 12,189-204.

Mountford, J.O. \& Sparks, T.H. (2019). Changes in the Vegetation of Wicken Fen NNR between 2010-12 and 2017-18. Final report to the National Trust.

Olff, H. \& Ritchie, M. E. (1998). Effects of herbivores on grassland plant diversity. Trends in Ecology and Evolution, 13, 261-265.

Pakeman, R. J. (2004). Consistency of plant species and trait responses to grazing along a productivity gradient: a multi-site analysis. Journal of Ecology, 92, 893-905.

Pavlů, L., Gaisler, J., Hejcmanová-Nežerková, P. \& Meneses, L. (2006). Changes in plant densities in a mesic species-rich grassland after imposing different grazing management treatments. Grass and Forage Science, 61, 42-51. https://doi. org/10.1111/j.1365-2494.2006.00506.x

Reke, A., Zarina, A \& Vinogradovs, I. (2019). Management of semi-wild large herbivores' grazing sites in Latvia. Proceedings of the 12th International Scientific and Practical Conference. Volume I, 241-244, Latvia.

Rodwell, J.S. (1991-2000). British Plant Communities (5 volumes). Cambridge: Cambridge University Press.

Rysiak, A., Chabuz, W., Sawicka-Zugaj, W., Zdulski, J., Grzywaczewski, G., \& Kulik, M. (2021). Comparative impacts of grazing and mowing on the floristics of grasslands in the buffer zone of Polesie National Park, eastern Poland. Global Ecology and Conservation, 27, e01612.Schaffers, A.P. \& Sykora, K.V. (2000). Reliability of Ellenberg indicator values for moisture, nitro- 
Peter A. Stroh et Al. - The effects of extensive grazing on the Vegetation of a landsCape-SCALe Restoration Site

gen and soil reaction: a comparison with field measurements. Journal of Vegetation Science, 11, 225-244, 2000.

Smit, C., Ruifrok, J. L., van Klink, R., \& Olff, H. (2015). Rewilding with large herbivores: The importance of grazing refuges for sapling establishment and wood-pasture formation. Biological Conservation, 182, 134-142. https://doi. org/10.1016/j.biocon.2014.11.047

Smith, R. S. and Rushton, S. P. (1994). The effects of grazing management on the vegetation of mesotrophic (meadow) grassland in northern England. Journal of Applied Ecology, 31, 13-24.

Soons, M. B. \& Bullock, J.M. (2008). Non-random seed abscission, long-distance wind dispersal and plant migration rates. Journal of Ecology, 96,581-590. https://doi:10.1111/j.13652745.2008.01370.x

Stace, C.A. (2010). New Flora of the British Isles. Third Edition. Cambridge University Press, Cambridge.

Stroh, P. A., Hughes, F.M.R., Sparks, T. \& Mountford, J.O. (2012a). The influence of time on the soil seed bank and vegetation across a landscape-scale wetland restoration project. Restoration Ecology, 20,103-112. https://doi. org/10.1111/j.1526-100X.2010.00740.x

Stroh, P.A. Hughes, F.M.R., \& Mountford, J.O. (2012b). The potential for endozoochorous dispersal of temperate fen plant species by free-roaming horses. Applied Vegetation Science, 15,359-368. https://doi.org/10.1111/ j.1654-109X.2011.01172.X

Stroh, P.A., Mountford, J.O., Araya, Y.N. \& Hughes, F.M.R. (2013). Quantifying soil hydrology to explain the development of vegetation at an ex-arable wetland restoration site. Wetlands, 33,311-320. https://doi.org/10.1007/s13157$\underline{013-0385-1}$
Stroh, P.A., Walker, K.J., Smith, S., Jefferson, R.J., Pinches, C. \& Blackstock, T. (2019). Grassland plants of the British and Irish lowlands. Botanical Society of Britain and Ireland, Durham.

Teunissen, B. (2019). The Oostvaardersplassen Fiasco. Isis 110(2) June 2019.

Tree, I. (2018). Wilding: The return of nature to a British Farm. London: Picador.

Ustaoglu, E and Collier, M.J. 2018 Farmland abandonment in Europe: an overview of drivers, consequences, and assessment of the sustainability implications. Environmental Reviews $31^{\text {st }}$ July 2018 https://doi.org/10.1139/er-20180001

Van Klink, R., Ruifrok, J.L. \& Smit C. (2016). Rewilding with large herbivores: Direct effects and edge effects of grazing refuges on plant and invertebrate communities. Agriculture, Ecosystems \& Environment, 234,81-97. https://doi. org/10.1016/j.agee.2016.01.050

Vera, F.W.M., Bakker, E.S., \& Olff, H. (2006). Large herbivores: missing partners of western European light-demanding tree and shrub species. In: Danell, K., Duncan, P., Bergström, R. \& J. Pastor (Eds.). Large Herbivore Ecology, Ecosystem Dynamics and Conservation (pp. 203-231). Cambridge: Cambridge University Press.

Vullink, J.T., Drost, H.J \& Jans, L. (2000). The influence of different grazing regimes on Phragmites and shrub vegetation in the welldrained zone of a eutrophic wetland. Applied Vegetation Science, 3,73-80. https://doi. org/10.2307/1478920 
Appendix 1: Species recorded in each of the nine study years. White cells indicate that a species was unrecorded, and increasing intensity of grey scale indicates recording in 1-2, 3-5, 6-9, 10-19, and 20-28 quadrats respectively.

Agrostis stolonifera Alopecurus myosuroides Alopecurus pratensis Anisantha sterilis Anthriscus sylvestris Arrhenatherum elatius Artemisia vulgaris Bidens tripartita

Brassica nigra

Bromus hordeaceus Calamagrostis canescens Calamagrostis epigejos Calystegia sepium Carex hirta

Carex otrubae

Carex riparia

Cerastium fontanum

Cirsium arvense

Convolvulus arvensis

Crataegus monogyna

Crepis vesicaria

Cynosurus cristatus

Dactylis glomerata

Deschampsia cespitosa

Eleocharis palustris

Elytrigia repens

Epilobium hirsutum

Epilobium parviflorum

Equisetum arvense

Eupatorium cannabinum

Festuca pratensis

Festuca rubra

Filipendula ulmaria

Fumaria muralis

Galium aparine

Galium palustre

Galium uliginosum

Geranium dissectum

Geranium pusillum

Glechoma hederacea

Heracleum sphondylium

Holcus lanatus

Hypericum tetrapterum

Juncus articulatus

Juncus compressus
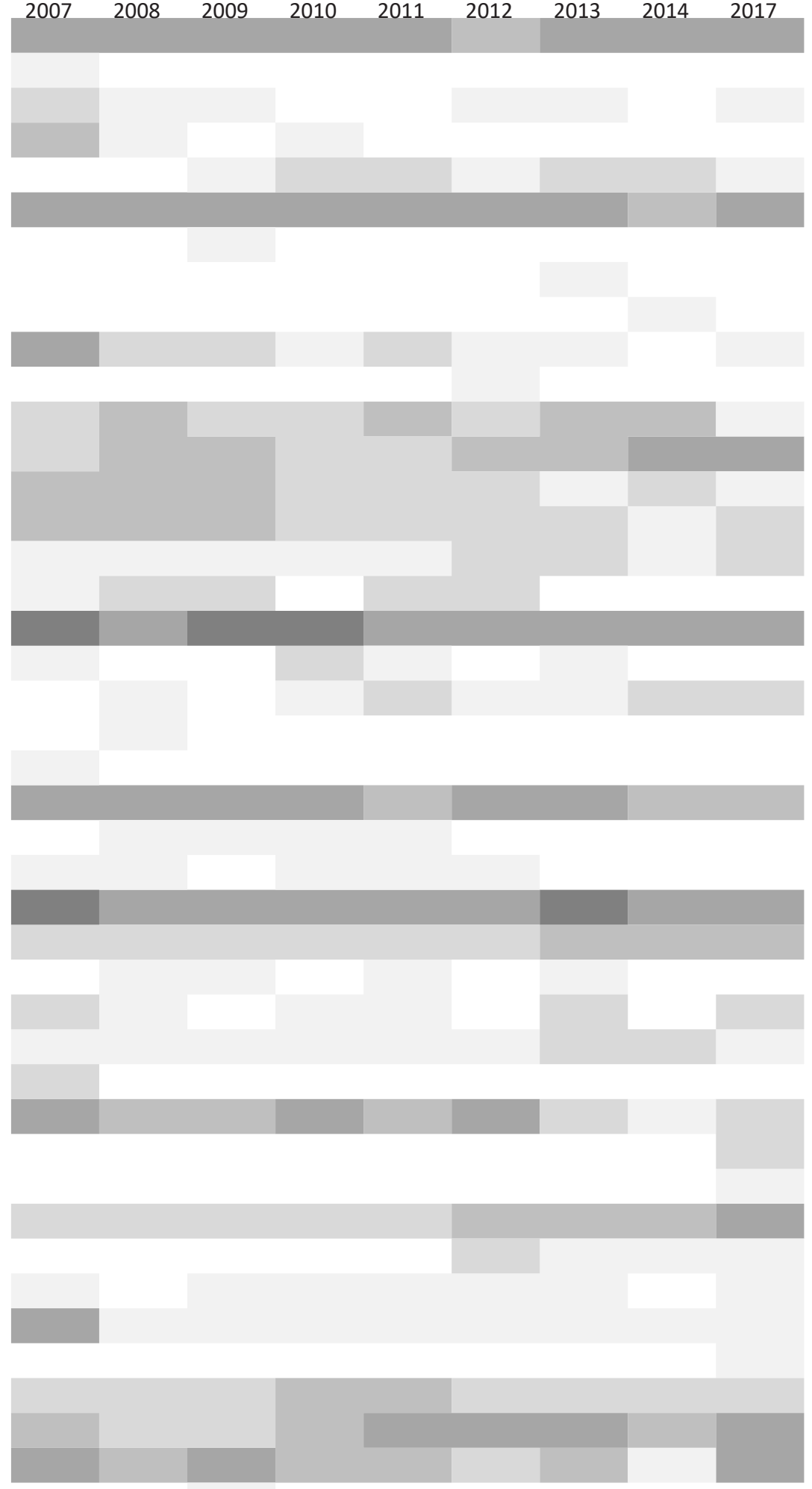
Peter A. Stroh et Al. - The effects of extensive graZing on the Vegetation of a landsCape-SCALe Restoration Site

Juncus inflexus

Juncus subnodulosus

Lamium album

Lolium perenne

Lycopus europaeus

Medicago lupulina

Mentha aquatica

Pastinaca sativa

Persicaria amphibia

Phalaris arundinacea

Phleum bertolonii

Phleum pratense

Phragmites australis

Picris echioides

Plantago lanceolata

Plantago major

Poa pratensis sens.lat.

Poa trivialis

Potentilla anserina

Prunella vulgaris

Ranunculus repens

Rhamnus cathartica

Rosa canina agg.

Rubus fruticosus agg.

Rumex acetosa

Rumex conglomeratus

Rumex crispus

Rumex obtusifolius

Salix caprea

Senecio jacobaea

Senecio squalidus

Sonchus asper

Stachys arvensis

Stellaria media

Taraxacum officinale

Thalictrum flavum

Tragopogon pratensis

Trifolium repens

Urtica dioica

Urtica dioica subsp. galeopsifolia

Viburnum opulus
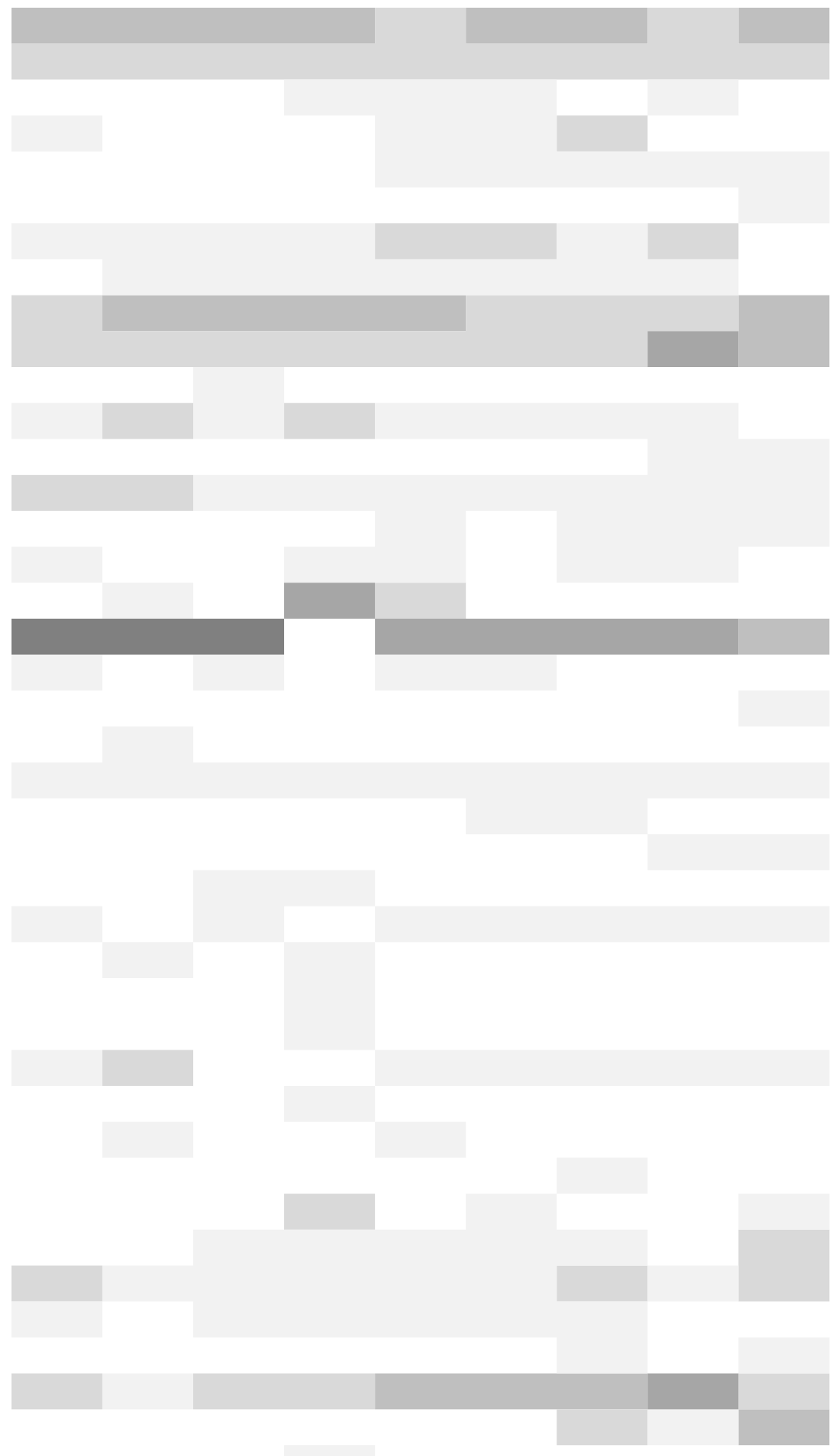